\title{
Immune mediated haemolytic anemia pada anjing siberian husky
}

\author{
Loisa, Nur Fitria Anggraini*, Talitha Khairunisa, Novri Wandi Bahar \\ Loisa Veterinary Clinic, Cibatu, Cikarang Selatan, Bekasi, Jawa Barat 17530
}

\begin{abstract}
ABSTRAK: Immune Mediated Haemolytic Anemia (IMHA) merupakan anemia yang muncul akibat hemolisis eritrosit di dalam pembuluh darah yang berhubungan dengan mediator sistem imun. Salah satu penyebab kondisi IMHA yaitu keberadaan parasit darah (Babesia sp.) dengan vektor caplak (Rhipicephalus sanguineus). Diagnosa IMHA yang disebabkan oleh infeksi Babesia sp pada anjing kasus ini terlihat melalui pemeriksaan sitologi dengan ditemukannya spherocyte dan terjadi hemolisis intravaskular sehingga masuk dalam kategori secondary IMHA. Pemeriksaan fisik di abdomen bagian kanan teraba adanya massa keras dan dilanjutkan pemeriksaan ultrasonografi dan radiografi. Hasil pemeriksaan ultrasonografi ditemukan adanya hepatomegali dan splenomegali. Hasil radiografi bagian thoraks tampak adanya tromboemboli di paru-paru, sedangkan pada bagian abdomen menunjukkan adanya internal bleeding. Berdasarkan hasil pemeriksaan darah menunjukkan rendahnya MCV dan MCHC (anemia mikrositik hipokromik oleh hemolisis), serta peningkatan RBC yang disebabkan oleh produksi RBC (eritrogenesis) khususnya retikulosit. Infeksi Babesia sp. pada anjing ini tampak pada tingginya persentase granulosit. Kejadian IMHA merupakan kondisi kronis, sehingga untuk mencegah IMHA diperlukan edukasi secara menyeluruh mengenai bahaya dampak infeksi ektoparasit (tick dan fleas) dalam jangka panjang dan cara mengendalikan ektoparasit.

Kata kunci:

Immune Mediated Haemolytic Anemia (IMHA), Babesia sp., Spherocyte
\end{abstract}

\section{- PENDAHULUAN}

Immune Mediated Haemolytic Anemia (IMHA) merupakan anemia yang muncul akibat hemolisis eritrosit di dalam intravaskular maupun ekstravaskular yang berhubungan dengan mediator sistem imun (Mackin, 2014). Kejadian ini dapat disebabkan oleh infeksi protozoa atau parasit darah, salah satunya Babesia sp (Mackin, 2014). Penularan parasit darah ini diperantai oleh vektor caplak yaitu Rhipicephalus sanguineus yang hidup di permukaan kulit anjing dan menghisap darah melalui pembuluh darah perifer di bawah kulit sehingga sangat berpotensi menyebabkan kerusakan eritrosit yang berujung dengan kejadian anemia.

\section{- KASUS}

Anamnesa: Lemas, kelumpuhan (tidak bisa berdiri), tidak mau makan 2-3 hari, minum banyak, tidak muntah, diare tetapi jumlah feses yang keluar sedikit, dipegang daerah perut marah dan mau menggigit, sering dikeluarkan oleh penjaga pabrik setiap malam dan sering terlihat mengacak tempat sampah (pemilik curiga memakan benda asing), pernah terinfeksi ektoparasit (kutu dan caplak) 2 tahun lalu, steril (ovariohisterektomi, OHE). Sinyalemen: nama hewan Crystal, anjing, Siberian Husky, betina, \pm 11 tahun, $\mathrm{T}=37.8{ }^{\circ} \mathrm{C}, \mathrm{BW}=21 \mathrm{~kg}, \mathrm{BCS}=3$. Gejala klinis/patologis: Hematuria, poliuria, polidipsi, splenomegali, hepatomegali, letargi, dehidrasi, CRT > 2 detik, membran mukosa anemis, jantung aritmia, nafas frekuen, palpasi abdomen keras dan anjing kesakitan, serta ditemukan caplak. Uji Pendukung: Hematologi, biokimiawi darah, rontgen, USG, sitologi, tes kit anaplasma dan erlichia. Diagnosis: Immune Mediated
Haemolytic Anemia (IMHA). Prognosis: Infausta. Terapi: Antibiotik, multivitamin, dan analgesik.

\section{- PEMBAHASAN}

Kondisi IMHA sering terjadi pada anjing tua dengan kondisi akut maupun kronis. Sitologi dalam kasus ini sangat membantu dalam mendiagnosa, karena pada hasil sitologi tampak adanya spherocyte yang menunjukan bahwa kasus anjing bernama Crystal ini mengalami kondisi IMHA (Gambar 1a). Menurut Mackin (2014), adanya spherocyte terjadi ketika makrofag menghilangkan sebagian membran RBC tanpa mendestruksi sel RBC sehingga RBC secara signifikan kehilangan sitoplasma. Kondisi IMHA yang terjadi pada anjing Crystal termasuk ke dalam secondary IMHA yang disebabkan oleh infeksi Babesia sp. dan mengakibatkan hemolisis intravaskular. Dari hasil pemeriksaan test kit antibodi Anaplasma sp., dan Ehrlicia sp. menunjukan hasil negatif.

Pemeriksaan fisik, teraba adanya massa keras di abdomen bagian kanan. Pemeriksaan ultrasonografi, ditemukan adanya hepatomegali dan splenomegali (Gambar 1b). Hal tersebut dikarenakan MPS (mononuclear phagocyte system) terjadi dalam hati dan limpa, yang merupakan tempat utama destruksi RBC (Mackin 2014). Berdasarkan hasil radiografi bagian thoraks (Gambar 1c), tampak adanya tromboemboli

Diterima: 04-02-2018 | Direvisi: 12-03-2018 | Disetujui: 26-03-2018 (C) 2018 CC-BY-SA. Ini adalah artikel Open Access yang didistribusikan berdasarkan ketentuan dari Creative Commons Attribution ShareAlike 4.0 International License (https://creativecommons.org/licenses/by-sa/4.0/). 
pada paru-paru. Pulmonary thromboembolism (PTE) sering terjadi pada anjing yang yang terkena IMHA. Sebagaimana penjelasan Carr et al. (2002) bahwa thrombus juga dapat ditemukan di organ internal lainnya. Radiografi bagian abdomen (Gambar 1d) menunjukkan adanya internal bleeding di daerah abdomen, yang diakibatkan oleh abnormalitas dalam proses pembekuan darah yang menyebabkan trombositopenia.

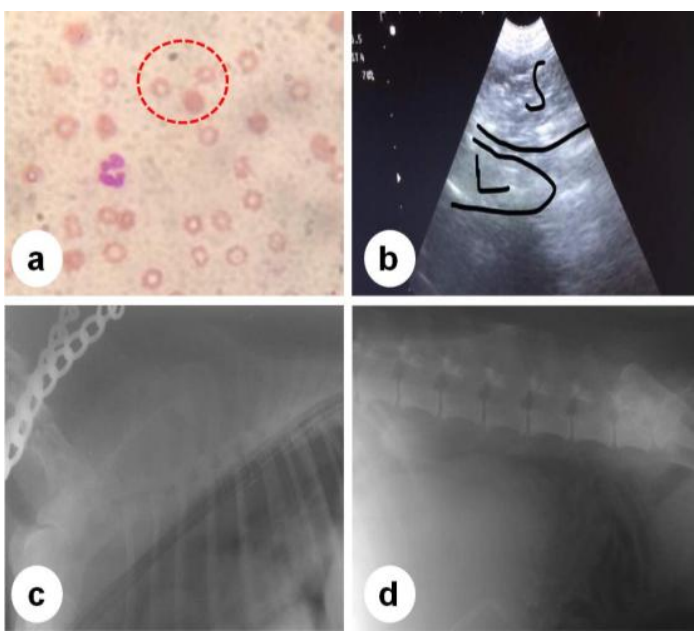

Gambar 1 Spherocyte dalam darah, sel darah dalam lingkaran titik-titik merah (a); hasil ultrasonografi, splenomegali dan hepatomegali (b); hasil radiografi, pulmonary thromboembolism (c) dan terjadi internal bleeding pada daerah abdomen (d).

Tabel 1 Hasil pemeriksaan darah lengkap dan kimia darah

\begin{tabular}{|l|c|c|c|c|}
\hline & Hasil & Kisaran Normal & Satuan & Keterangan \\
\hline WBC & $5.5 \times 10^{3}$ & $6-17$ & $/ \mathrm{uL}$ & Low \\
\hline LYM\# & $0.3 \times 10^{3}$ & $0.8-5.1$ & $/ \mathrm{uL}$ & Low \\
\hline MID\# & $0.1 \times 10^{3}$ & $0-1.8$ & $/ \mathrm{uL}$ & \\
\hline GRA\# & $5.1 \times 10^{3}$ & $4-12.6$ & $/ \mathrm{uL}$ & \\
\hline LYM\% & 4.8 & $12-30$ & $\%$ & Low \\
\hline MID\% & 1.3 & $2-9$ & $\%$ & Low \\
\hline GRA\% & 93.9 & $60-83$ & $\%$ & High \\
\hline RBC & $8.76 \times 10^{6}$ & $5.5-8.5$ & $/ \mathrm{uL}$ & High \\
\hline HGB & 14.3 & $11-19$ & $\mathrm{~g} / \mathrm{dL}$ & Normal \\
\hline MCHC & 27.3 & $30-38$ & $\mathrm{~g} / \mathrm{dL}$ & Low \\
\hline MCH & 16.3 & $20-25$ & $\mathrm{Pg}$ & Low \\
\hline MCV & 59.9 & $62-72$ & $\mathrm{fL}$ & Low \\
\hline RDW-CV & 15.6 & 11.55 .5 & $\%$ & High \\
\hline RDW-SD & 38.6 & $35-56$ & $\mathrm{fL}$ & Normal \\
\hline HCT & 52.5 & $39-56$ & $\%$ & Normal \\
\hline PLT & $75 \times 10^{3}$ & $117-460$ & $/ \mathrm{uL}$ & Low \\
\hline MPV & 7.1 & $7-12.9$ & $\mathrm{fL}$ & Normal \\
\hline PDW & 8.1 & $10-18$ & $\mathrm{fL}$ & Low \\
\hline PCT & 0.053 & $0.1-0.5$ & $\%$ & Low \\
\hline P-LCR & 9.9 & $13-43$ & $\%$ & Low \\
\hline AST & 5.50 & $8.9-48.5$ & $\mathrm{IU} / \mathrm{L}$ & Low \\
\hline ALP & 157.00 & $10.6-100.7$ & $\mathrm{IU} / \mathrm{L}$ & High \\
\hline ALT & 51.68 & $8.2-57.3$ & $\mathrm{IU} / \mathrm{L}$ & Normal \\
\hline Urea & 20.07 & $15-40$ & $\mathrm{mg} / \mathrm{dL}$ & Normal \\
\hline Creatinin & 0.71 & $0.5-1.5$ & $\mathrm{mg} / \mathrm{dL}$ & Normal \\
\hline
\end{tabular}

RBC tua normalnya akan dimusnahkan di dalam hati dan limpa melalui mekanisme MPS. IMHA termasuk reaksi hipersensitivitas tipe II dengan antibodi anti-RBC (termasuk $\mathrm{IgG}$, IgM, dan $\operatorname{Ig} \mathrm{A}$ ) yang melekat secara langsung maupun tidak langsung pada membran RBC. Perlekatan pada membran sel RBC ini menyebabkan hemolisis intravaskular, hemolisis ekstravaskular, dan aglutinasi intravaskular RBC. Hemolisis intravaskular terjadi karena antibodi melekat pada membran RBC dan mengaktivasi komplemen yang mengakibatkan kerusakan membran RBC, cairan ekstraselular masuk ke dalam RBC dan sel RBC menjadi ruptur dalam sirkulasi darah. Kejadian ini akan mengakibatkan lepasnya hemoglobin ke dalam plasma darah (hemoglobinemia) dan hemoglobinnuria (Balch \& Mackin 2007). IMHA dan IMTP (Immune mediatedthrombocytopenia) dapat terjadi secara bersamaan yang melibatkan produksi dari antibodi anti platelet (Day 2012; Stone 2010). Menurut Day (2012), penyakit ini juga dapat mengakibatkan terjadinya IMNV (Immune mediated neutropenia) pada anjing.

Berdasarkan hasil pemeriksaan darah, menunjukkan rendahnya MCV dan MCHC (anemia mikrositik hipokromik oleh hemolisis), peningkatan RBC karena produksi RBC (eritrogenesis) yang tinggi khususnya retikulosit untuk pemenuhan kurangnya kebutuhan $\mathrm{RBC}$ akibat hemolisis. Infeksi Babesia sp. pada anjing Crystal tampak dari tingginya persentase granulosit (Tabel 1). Menurut Sharp dan Kerl (2008), peningkatan ALP diduga disebabkan oleh kolestasis dari hiperplasia MPS dalam hati atau hepatic extramedullary hematopoiesis.

\section{- SIMPULAN}

Kejadian IMHA merupakan kondisi kronis yang terjadi akibat manifestasi caplak yang membawa parasit darah (Babesia sp.). Sitologi ulas darah dapat digunakan untuk mendiagnosa kasus IMHA dengan ditemukan adanya spherocyte. Untuk mencegah kondisi IMHA diperlukan edukasi secara menyeluruh mengenai dampak infeksi ektoparasit (tick dan fleas) dalam jangka panjang dan cara mengendalikan ektoparasit tersebut. Edukasi yang baik pada klien tentang bahaya parasit darah (Babesia sp.) pada anjing diharapkan mampu mencegah terjadinya kasus IMHA.

\section{- INFORMASI PENULIS}

Penulis untuk korespondesi

*NFA: nurfitria.anggraini@yahoo.com

Loisa Veterinary Clinic, Cibatu, Cikarang Selatan, Bekasi, 17530.

\section{- PUSTAKA ACUAN}

Balch A, Mackin. 2007. Canine immune-mediated hemolytic anemia: patophysiology, clinical signs, and diagnosis. Compend Contin Educ Vet. 29(4):217-225.

Carr AP, Panciera DL, Kidd L. 2002. Prognostic factor for mortality and thromboembolism in canine immune-mediated hemolytic anemia: a retrospective study of 72 dogs. J Vet Intern Med. 16:504-509.

Day MJ. 2012. Canine-immunomediated hemolytic anemia. NAVC Clinician's Brief. October: 53-57.

Mackin A. 2014. Immune-mediated hemolytic anemia: pathophysiology and diagnosis. DVAVM: Mississippi University. http://www.delawarevalleyacademyvm.org/pdfs/oct14/Autoimmun e.pdf

Sharp C, Kerl ME. 2008.Standard of Care Emergency and Critical Care Management: Immune Mediated-Hemolytic Anemia. 10(10): 1-6. http://studyres.com/doc/7841642/immune-mediated-hemolyticanemia

Stone M. 2010. Ettinger: Textbook of Veterinary Internal MedicineImmune Mediated Hemolytic Anemia and Immune Mediated Thrombocytopenia. $7^{\text {th }}$ Ed. Saunders: Elsevier. 